\title{
Through the Eye of a Needle: An Eco-Heterodox Perspective on the Renewable Energy Transition
}

\author{
Megan K. Seibert ${ }^{1, *}$ and William E. Rees ${ }^{1,2}$ \\ 1 The REAL Green New Deal Project, Albany, OR 97321, USA \\ 2 Faculty of Applied Science, School of Community and Regional Planning, University of British Columbia, \\ Vancouver, BC V6T 1Z2, Canada; wrees@mail.ubc.ca \\ * Correspondence: megan.seibert@realgnd.org
}

Citation: Seibert, M.K.; Rees, W.E. Through the Eye of a Needle: An Eco-Heterodox Perspective on the Renewable Energy Transition. Energies 2021, 14, 4508. https:// doi.org/10.3390/en14154508

Academic Editor: Alessia Arteconi

Received: 23 June 2021

Accepted: 20 July 2021

Published: 26 July 2021

Publisher's Note: MDPI stays neutral with regard to jurisdictional claims in published maps and institutional affiliations.

Copyright: (c) 2021 by the authors. Licensee MDPI, Basel, Switzerland. This article is an open access article distributed under the terms and conditions of the Creative Commons Attribution (CC BY) license (https:/ / creativecommons.org/licenses/by/ $4.0 /)$.

\begin{abstract}
We add to the emerging body of literature highlighting cracks in the foundation of the mainstream energy transition narrative. We offer a tripartite analysis that re-characterizes the climate crisis within its broader context of ecological overshoot, highlights numerous collectively fatal problems with so-called renewable energy technologies, and suggests alternative solutions that entail a contraction of the human enterprise. This analysis makes clear that the pat notion of "affordable clean energy" views the world through a narrow keyhole that is blind to innumerable economic, ecological, and social costs. These undesirable "externalities" can no longer be ignored. To achieve sustainability and salvage civilization, society must embark on a planned, cooperative descent from an extreme state of overshoot in just a decade or two. While it might be easier for the proverbial camel to pass through the eye of a needle than for global society to succeed in this endeavor, history is replete with stellar achievements that have arisen only from a dogged pursuit of the seemingly impossible.
\end{abstract}

Keywords: renewable energy; energy transition; overshoot; biocapacity; ecological limits; social justice; sustainability

\section{Introduction}

We begin with a reminder that humans are storytellers by nature. We socially construct complex sets of facts, beliefs, and values that guide how we operate in the world. Indeed, humans act out of their socially constructed narratives as if they were real. All political ideologies, religious doctrines, economic paradigms, cultural narratives-even scientific theories-are socially constructed "stories" that may or may not accurately reflect any aspect of reality they purport to represent. Once a particular construct has taken hold, its adherents are likely to treat it more seriously than opposing evidence from an alternate conceptual framework.

The Green New Deal (GND) is the dominant aspirational pathway in the mainstream narrative for achieving socially just ecological sustainability. Its central message is that a smooth transition away from climate-hostile fossil fuels is a relatively simple technological matter. Not only do proponents claim that electrification of all energy consumption by means of high-tech wind turbines and solar photovoltaic (PV) panels is technically possible, but that such a vast and unprecedented replacement of society's entrenched energy foundation is both financially feasible and carries the added benefit of creating thousands of "green" jobs [1-7]. The only missing ingredient, we are told, is political will. Energy transition plans produced by numerous academic institutions and researchers around the world support or conform obediently to the GND paradigm, and politicians everywhere have taken up the GND banner as the core of their environmental pledges.

We argue that while the GND narrative is highly seductive, it is little more than a disastrous shared illusion. Not only is the GND technically flawed, but it fails to recognize human ecological dysfunction as the overall driver of incipient global systemic collapse. 
By viewing climate change, rather than ecological overshoot-of which climate change is merely a symptom - as the central problem, the GND and its variants grasp in vain for techno-industrial solutions to problems caused by techno-industrial society. Such a self-referencing pursuit is doomed to fail. As Albert Einstein allegedly said, "we cannot solve our problems with the same thinking we used when we created them". We need an entirely new narrative for a successful energy transition. Only by abandoning the flawed paradigmatic source of our ecological dilemma can we formulate realistic pathways for averting social-ecological collapse.

\section{Climate Change in the Context of Overshoot}

Long-standing calls from ecologists and informed environmentalists for society to adopt a systems perspective and employ a multi-disciplinary approach to anthropogenic climate change have largely fallen on deaf ears. Most people have succumbed to the mechanistic-reductionist paradigm that has dominated Cartesian science, as is evident by the isolation of climate from its broader ecological context and its treatment as a discrete, independent variable. The reality is that climate change is only one symptom of systems destabilization as the human enterprise has come to overwhelm the ecosphere.

To recalibrate our focal lens, consider the following accelerating changes. The population of $H$. sapiens is nearly eight times larger than it was at the beginning of the fossil-fueled Industrial Age a mere 200 years ago, and it has been growing nearly 20 times faster [8]. To accommodate the explosion of humanity, over half the land surface of Earth has been substantially modified, particularly for agriculture (that most ecologically destructive of technologies). One consequence of this is the competitive displacement of non-human species from their habitats and food sources. Prior to the dawn of agriculture eight to ten millennia ago, humans accounted for less than $1 \%$, and wild mammals $99 \%$, of mammalian biomass on Earth. Today, H. sapiens constitute 36\%, and our domestic livestock another $60 \%$, of a much-expanded mammalian biomass, compared with only $4 \%$ for all wild species combined [9-11]. McRae et al. [12] estimate that the populations of non-human vertebrate species declined by 58\% between 1970 and 2012 alone. Freshwater, marine, and terrestrial vertebrate populations declined by $81 \%, 36 \%$, and $38 \%$, respectively, and invertebrate populations fell by about $50 \%$.

While fossil fuels (FFs) — coal and later oil and natural gas-have been humanity's major source of energy over the past two centuries, $50 \%$ of all FFs ever burned have been consumed in just the past 30 years (as much as $90 \%$ since the early 1940s) as superexponential growth has taken hold [13,14]. It should be no surprise, therefore, that carbon dioxide emissions - the major material by-product of FF combustion and principal anthropogenic driver of climate change-have long exceeded photosynthetic uptake by green plants. By 1997 (when annual consumption was 40\% less than in 2021), humanity was already burning FFs containing about 422 times the net amount of carbon fixed by photosynthesis globally each year [15]. Between 1800 and 2021, atmospheric carbon dioxide concentrations increased by $48 \%$, from $280 \mathrm{ppm}$ to approximately $415 \mathrm{ppm}$.

These data show that plunging biodiversity and climate change, along with air/land/ ocean pollution, deforestation, desertification, incipient resources scarcity, etc., are the inevitable consequences - indeed, parallel symptoms - of the same root phenomenon: the spectacular and continuing growth of the human enterprise on a finite planet. $H$. sapiens is in overshoot, exploiting ecosystems beyond their regenerative and assimilative capacities.

Overshoot is possible only because of: (a) the short-term availability of prodigious stocks of both renewable (fish, forest, soil, etc.) and non-renewable (coal, oil, natural gas, etc.) forms of so-called "natural capital"; and (b) the enormous, but finite, natural waste assimilation and recycling processes of the ecosphere. However, a reckoning is at hand. In just a few decades of geometric population and economic growth, humans have exploited (often to collapse) natural capital stocks that took millennia to accumulate and have impeded natural life-support processes through excessive, often toxic, waste discharges. The human enterprise now uses the bio-productive and assimilative capacities of 1.75 Earth 
equivalents [16]. In simple terms, the industrial world's ecological predicament is the result of too many people consuming too much and over-polluting the ecosphere.

Clearly, the climate crisis cannot be solved in isolation from the macro-problem of overshoot-certainly not by using technologies that are reliant on the same FFs and ecologically destructive processes that created the problem in the first place.

\section{Problems with So-Called Renewables}

Here, we holistically examine renewable energy (RE), focusing on the widely overlooked limitations of the RE technologies commonly set forth as solutions (but that do not constitute all possible RE options). This examination shows that RE cannot deliver the same quantity and quality of energy as FFs, that the espoused technologies are not renewable, that their production - from mining to installation-is fossil-energy-intensive, and that producing them-particularly mining their metals and discarding their waste-entails egregious social injustices and significant ecological degradation.

The challenge before us is to identify which RE technologies are both sustainable and viable. Sustainability implies the ability to persist in perpetuity with minimal negative environmental impacts (i.e., within ecological limits). Viability entails basic, practical issues for production and implementation (e.g., is it possible to build and implement the RE technology without FF inputs? Can it be done on a climate-relevant schedule? Is it affordable?). Within this context, such pat slogans as " $100 \%$ clean energy" and "net zero emissions" must be discarded. Every energy-producing technology-no matter how rudimentary or advanced-uses inputs from the environment and produces pollution or other ecological degradation over its life cycle. Trade-offs must be assessed. Just because raw sunlight and wind are "clean" and continuous energy flows does not mean that harnessing them to perform work is. While we inevitably face a future underpinned entirely by RE, the question is not how to meet current total demand, but rather to determine: (a) which RE technologies are actually sustainable and viable; (b) the contexts in which they might be so, including the priority uses to which they might be applied; and (c) how to effectively and fairly reduce energy demand.

GND proponents are appallingly tolerant of the inexplicable. They fail to address how the gigatons of already severely depleted metals and minerals essential to building so-called $\mathrm{RE}$ technologies will be available in perpetuity considering typical five to 30-year life spans and the need for continuous replacement [17-19]. They offer no viable workarounds for the ecological damage and deplorable working conditions, often in the Global South, involved in metal ore extraction $[20,21]$. Green New Dealers advance no viable solutions (technical or financial) for electrifying the many high-heat-intensive manufacturing processes involved in constructing high-tech wind turbines and solar panels (not to mention all other products in modern society) [22-25]. The waste streams generated by so-called renewables at the end of their short working lives are either ignored or assumed away, to be dealt with eventually by yet non-existent recycling processes [26-28]. Proposals for electrifying the $80 \%$ of nonelectrical energy demand overlook crucial facts, namely that the national-scale transmission systems and grids required for electrified land transportation do not even exist today, nor is the needed build-out likely given material, energy, and financial constraints [29].

Finally, as emphasized previously, the quest for a magical source of free energy ignores the overriding overshoot crisis-which, paradoxically, was enabled by abundant, cheap fossil energy. We argue that the only viable response to overshoot is a managed contraction of the human enterprise until we arrive within the safely stable territory defined by ecological limits. This will entail many fewer people consuming far less energy and material resources than at present.

Obviously, a managed descent will require a paradigmatic shift in society's socially constructed values, beliefs, and assumptions. At a minimum, we must replace our unrelenting anthropocentricism and strictly instrumental approach to Nature with a more holistic, eco-centric perspective. People must come to acknowledge both their utter dependence on the integrity of the ecosphere and the intrinsic worth of other species and 
natural ecosystems. This means overcoming capitalism's addiction to material growth and adopting systems compatible with one-Earth living ('one-Earth living' implies any material standard of living that, if extended to everyone on Earth, would be sustainable-i.e., the human population would be living within the global carrying capacity [30]. Obviously, the more people, the lower the average sustainable standard of living).

Far from encouraging such a radically new paradigm, the GND promotes an ecowashed version of the status quo with its unquestioning faith that technology will save us and its comforting narrative of business-as-usual by alternative means. This myth has become so well accepted in the public and academic mind that to question it is to be perceived as anti-renewable, pessimistically discounting human ingenuity, or even a shill for the FF industry. Those who do venture critical observations often do so with trepidation and constraint.

The following eco-heterodox view of the renewable energy transition flows from our commitment to critical discourse and stewardship of our one and only planet. This perspective widens the lens of analysis and confronts naked realities that can no longer be ignored. Our overriding goal is to assist society in developing a considered appreciation of what a truly renewable energy landscape might look like.

\subsection{The Electrification Question}

Only $19 \%$ of global final energy consumption is in the form of electricity. The other $81 \%$ is in the form of liquid fuel [31]. There are formidable obstacles to converting electricity consumption alone to so-called renewable sources.

\subsubsection{Big Picture Sanity Check}

Transitioning the U.S. electrical supply away from FFs by 2050 would require a grid construction rate 14 times that of the rate over the past half century [32]. The actual installed costs for a global solar program would have totaled roughly $\$ 252$ trillion (about 13 times the U.S. GDP) a decade ago [33], and considerably more today. A recent report describing what would be needed to achieve 90\% "decarbonization" and electrification by 2035 neglects to mention that, in order to meet such targets, the United States would have to quadruple its last annual construction of wind turbines every year for the next 15 years and triple its last annual construction of solar PV every year for the next 15 years-only to repeat the process indefinitely since solar panels and wind turbines have average lifespans of around 15 to 30 years [34,35]. In addition, Clack et al. [36] found that one of the most cited studies on $100 \%$ electrification in the United States is error-prone and laden with untenable assumptions.

\subsubsection{Heat for Manufacturing}

The manufacturing processes used today to make solar panels, high-tech wind turbines, batteries, and all other industrial products involve very high temperatures that are currently generated using FFs. Despite the critical importance of heat in manufacturing, there is scant information on whether or how it can be generated with RE alone.

Approximately $30 \%$ of industrial heating applications require temperatures below $212^{\circ} \mathrm{F}\left(100{ }^{\circ} \mathrm{C}\right) ; 27 \%$ can be met with temperatures between $212^{\circ} \mathrm{F}$ and $750{ }^{\circ} \mathrm{F}\left(100{ }^{\circ} \mathrm{C}\right.$ and $\left.400{ }^{\circ} \mathrm{C}\right)$; and $43 \%$ require temperatures above $750^{\circ} \mathrm{F}\left(400^{\circ} \mathrm{C}\right)$ [37]. Most existing RE heating technologies can supply heat only within the lowest temperature category [37]. This is highly problematic given that solar panel manufacturing requires temperatures ranging from $2700{ }^{\circ} \mathrm{F}$ to $3600{ }^{\circ} \mathrm{F}\left(1480{ }^{\circ} \mathrm{C}\right.$ to $\left.1980{ }^{\circ} \mathrm{C}\right)$ and the steel and cement manufacturing for high-tech wind turbines, hydropower plants, and nuclear plants require temperatures ranging from $1800^{\circ} \mathrm{F}$ to $3100^{\circ} \mathrm{F}\left(980^{\circ} \mathrm{C}\right.$ to $\left.1700^{\circ} \mathrm{C}\right)$.

According to the U.S. Energy Information Administration [38], natural gas, petroleum, electricity, and coal are the current sources of industrial energy, with natural gas and petroleum being predominant. If modern industrial manufacturing-responsible for generating the seemingly countless components of so-called RE technologies-is to continue 
without FFs, renewable-based technologies must be developed that would supply seamless replacements for high-heat sources of energy at acceptable economic and ecological costs.

Existing reports explore numerous RE heat sources for manufacturing, including various forms of bioenergy, concentrated solar power (CSP), hydrogen, geothermal, and nuclear [22-25]. We discuss each in turn as they relate to the fossil energy sources they could potentially replace.

Possible replacements for natural gas include biomethane and hydrogen. Biomethane is a near-pure source of methane derived from one of two methods: the "upgrading" of biogas or gasified woody biomass. Biogas is a mixture of gases that results from the breakdown of agricultural, livestock, and household waste; sewage in wastewater treatment plants; and municipal waste (i.e., the anaerobic digestion of organic matter in an oxygen-free environment). Gasification entails heating wood in a low oxygen environment to produce synthetic gas, or syngas. The upgrading process involves removing nearly all gases in the biogas and syngas except for methane.

Problems abound with biomethane as an industrial energy replacement option. At present, biogas upgrading accounts for roughly $90 \%$ of all biomethane production [39]. From a technological standpoint, all five commercially viable processes for biogas upgrading have disadvantages, if not outright roadblocks, that limit their production and viability. The polyethylene glycol used in one type of physical scrubbing is a derivative of petroleum, and the other form of water-based physical scrubbing requires significant amounts of water and electricity $[40,41]$. Chemical scrubbing involves toxic solvents that are costly and difficult to handle, and it has a high heat demand [40-42]. Despite low energy and financial inputs [40], membrane separation involves fragile and short-lived membranes (lasting 5-10 years) [42] and produces relatively low methane purity [40]. Pressure swing adsorption is a highly complex process [40,42], and neither cryogenic separation nor biological methods are yet commercially viable $[42,43]$. Moreover, not all upgrading technologies are energetically self-sufficient-many, if not most, rely on FFs [41]. Problematically, upgrading biogas produces $\mathrm{CO}_{2}[40,41]$. Carbon capture and storage is one proposal for dealing with the resulting $\mathrm{CO}_{2}$ but presents ecological problems and high costs [40]. Gasification has yet to be deployed at a large industrial scale [43].

There are additional problems with feedstock and co-location requirements. Current waste streams are insufficient to support the widespread use of biomethane in the transportation sector, let alone the industrial sector [44]. It is estimated that the maximum practical contribution of biomethane via biogas and gasification is only around $11 \%$ of Europe's current total natural gas consumption [43]. Harvesting woody biomass for gasification would have to be judiciously considered within the broader context of its sustainable management. Given the post-FF transportation limitations discussed later, biomethane production facilities would have to be co-located with feedstock sites, which would then have to be co-located with manufacturing sites. These requirements present obvious challenges, if not outright roadblocks.

The single greatest problem with producing hydrogen is that, regardless of method, more energy is required to produce and compress the product than it can later generate $[22,25,29,33]$. The only viable, large-scale feedstock for hydrogen is natural gas, and the gas reforming process requires temperatures ranging from $1300^{\circ} \mathrm{F}$ to $1830^{\circ} \mathrm{F}\left(700^{\circ} \mathrm{C}\right.$ to $\left.1000^{\circ} \mathrm{C}\right)[25,29,33,45]$. Gas reforming produces substantial greenhouse gas (GHG) emissions and presents numerous problems in the way of leakage, corrosion, and accidental combustion [22,25,45].

Potential replacements for petroleum (i.e., crude oil) include bioethanol (ethanol made from corn or other fermented plant matter) and biodiesel. As discussed later, the land requirements for feeding $8+/$ - billion people without FF inputs preclude the large-scale use of cropland and plant biomass for energy purposes, even if net energy was satisfactory.

Contenders for non-fossil-generated electricity include geothermal, nuclear, concentrated solar power (CSP), solar PV, and wind turbines. Geothermal systems produce temperatures of around only $300^{\circ} \mathrm{F}\left(150^{\circ} \mathrm{C}\right)$ and must be located in mountainous regions 
with active tectonic plate movement or near volcanic hot spots [24]. Production wells are commonly up to two kilometers deep $[23,24]$ - depths that can be reached only with fossil-fueled machinery and advanced technologies. As discussed later, nuclear has massive water and material requirements. Facilities cannot be built and maintained without fossil-fueled machinery, and there is the still-unsolved problem of dangerous radioactive waste disposal. The much-touted small modular reactors (SMRs) are still in the R\&D phase, still produce radioactive byproducts that must be disposed of, and pose the problem of transportability. Despite theoretical upper temperature limits ranging from $1800{ }^{\circ} \mathrm{F}$ to $2200{ }^{\circ} \mathrm{F}\left(1000^{\circ} \mathrm{C}\right.$ to $\left.1200{ }^{\circ} \mathrm{C}\right)$, existing CSP systems generate heat in the range of only $300{ }^{\circ} \mathrm{F}$ to $570{ }^{\circ} \mathrm{F}\left(150{ }^{\circ} \mathrm{C}\right.$ to $\left.300^{\circ} \mathrm{C}\right)[22,24]$. CSP plants typically cost in excess of $\$ 1$ billion and require around five square miles of land. Though they can store thermal energy in molten salt, the on-site salt stores less than one day's worth of electrical supply and almost all CSP plants have a fossil backup to diminish thermal losses at night, prevent the molten salt from freezing, supplement low solar radiance in the winter, and for fast starts in the morning $[22,29]$. The DC electricity generated by wind and solar PV can only be stored in batteries, which presents serious ecological and practical problems, as discussed later.

The only potential replacement for coal is charcoal derived from wood. This poses two obvious problems. The remaining stock of woody biomass-vastly depleted during the Industrial Age-is nowhere close to supporting current manufacturing needs, particularly recognizing the need to set aside half of the Earth's major eco-regions to ensure the functional integrity and health of the ecosphere [46]. Even if a sustainable supply of an already-stretched renewable resource was not a concern, industrial furnaces/boilers and steel manufacturing equipment are specifically designed to function with thermal coal and coke (made from coking coal); switching to charcoal would require the redesign and reconstruction of entire systems.

Such roadblocks impede the electrification of all manufacturing processes that do not already use electricity. Even so, there has been little R\&D on massive electrification options. Additionally, again, since most existing fossil-powered equipment would require complex, large-scale system redesigns, $100 \%$ electrification of manufacturing would be extremely difficult, if not impossibly expensive [25].

In short, no RE source or system is viable if it cannot not generate sufficient energy both to produce itself (literally from the ground up) and supply a sufficient surplus for society's end-use consumption. Currently, no so-called RE technology is in the running.

\subsubsection{Problems with Solar Panels}

Manufacturing solar panels uses toxic substances, large quantities of energy and water, and produces toxic byproducts [33,47]. Mono-and poly-crystalline solar panels require high temperatures at every step of their production. For example, temperatures of $2700^{\circ}$ to $3600{ }^{\circ} \mathrm{F}\left(1500^{\circ}\right.$ to $\left.2000{ }^{\circ} \mathrm{C}\right)$ are needed to transform silicon dioxide into metallurgical-grade silicon. Up to half of the silicon is lost in the wafer sawing process. For every $1 \mathrm{MW}$ of solar panels produced, about 1.4 tonnes of toxic substances (including hydrochloric acid, sodium hydroxide, sulfuric acid, nitric acid, and hydrogen fluoride) and 2868 tonnes of water are used, while 8.6 tonnes of emissions are released -8.1 tonnes of which are the perfluorinated compounds sulfur hexafluoride $\left(\mathrm{SF}_{6}\right)$, nitrogen trifluoride $\left(\mathrm{NF}_{3}\right)$, and hexafluoroethane $\left(\mathrm{C}_{2} \mathrm{~F}_{6}\right)$ that are thousands of times more potent than $\mathrm{CO}_{2}$ [48]. Other toxic byproducts, such as trichlorosilane gas, silicon tetrachloride, and dangerous particulates from the wafer sawing process, are also produced. Amorphous (thin-film) solar panels are made with cadmium, which is a carcinogen and genotoxin.

The actual performance of installed solar panels is problematic $[33,49,50]$. The efficiency rates of solar panels are low (on average around 15\% to 20\%) and almost always less than what manufacturers advertise. Solar panels are highly sensitive and lose function in non-optimal conditions (e.g., when there is haze or humidity, if the panels are not angled properly, or if any obstructions-such as bird droppings, dust, snow, or pollution-block 
even small parts of the panel's surface). They become less efficient as they age, sometimes losing up to $50 \%$ efficiency.

Solar panels have a life span of only 20 to 30 years, making for a massive waste management problem. Inverters (which transform the DC output of solar panels into the AC input required by appliances) need to be replaced every five to eight years [33]. By the end of 2016, there were roughly 250,000 tonnes of solar panel e-waste globally, accounting for about $0.5 \%$ of all annual global e-waste [26]. According to the International Renewable Energy Agency [51], solar panel waste could amount to six million tonnes annually by 2050, and the cumulative waste by then could reach 78 million tonnes. By 2050, dead solar panels could account for $10 \%$ of all e-waste streams, and their cumulative end-of-life waste may be greater than all e-waste in 2018 [20]. The much-touted silver bullet of recycling is not the panacea is it purported to be. Recycling requires copious amounts of energy, water, and other inputs, and exposes workers to toxic materials that have to be disposed of. Currently, there are only two types of commercially available solar PV recycling and only a handful of recycling facilities around the world [26,27].

Even without such drawbacks, solar PV has a low energy return on energy invested (EROEI) - too low to power modern civilization [52-55].

\subsubsection{Problems with Batteries and Other Storage}

There are four primary types of commercially proven, grid-scale energy storage: pumped hydroelectric storage, compressed air energy storage, advanced battery energy storage, and flywheel energy storage. Pumped hydroelectric storage is possible only if hydroelectric dams are part of the system. Flywheel energy storage is used more for power management than long-term energy storage. Of the remaining two, compressed air storage is deployed at only two power plants in the world, with likely little expansion since it is quite inefficient and relies on large underground cavities with specific geological characteristics $[29,56,57]$. Only a few power plants in the United States have operational battery storage, accounting for $800 \mathrm{MW}$ of power capacity [56,58]. Consider that the United States consumes around 4000 terawatt-hours of electricity every year [59], or 563 times the existing battery storage capacity.

An entire year of production from the world's largest lithium-ion battery manufacturing facility-Tesla's \$5 billion Gigafactory in Nevada-could store only three minutes' worth of annual U.S. electricity demand [32]. Manufacturing a quantity of batteries that could store just two days' worth of U.S. electricity demand would require 1000 years of Gigafactory production [32]. Storing only $24 \mathrm{~h}$ worth of U.S. electricity generation in lithium batteries would cost $\$ 11.9$ trillion, take up 345 square miles, and weigh 74 million tons [29] - at enormous ecological cost. A battery-centric future means mining gigatons of rare-earth mineral ores. For every kilogram of battery, $50-100 \mathrm{~kg}$ of ore needs to be mined, transported, and processed [60]. Constructing enough lithium batteries to store only $12 \mathrm{~h}^{\prime}$ worth of daily power consumption would require 18 months' worth of global primary energy production and the entire global supply of several minerals [29].

Battery chemistry is complex, and improvements in one characteristic (e.g., energy density, power capability, durability, safety, or cost) always come at a cost to another. The monitoring and cooling systems and the steel used to encase the flammable lithium (other types of batteries are also flammable) weigh 1.5 times as much as the battery itself [29]. Batteries lose capacity over time, are negatively impacted by temperature extremes, pose safety issues that internal combustion engines do not [61], and have a poor energy-toweight ratio [62]. Batteries also have higher GHG emissions than internal combustion engines [63].

Not all vehicles and machinery used today can be powered by batteries. Small cranes, a crawler crane [64], light and some heavy-duty construction equipment, and passenger cars can be powered by batteries. However, other large cranes (used to load and unload cargo and in large construction projects, mining operations, and more), container and other large ships, airplanes, and heavy-duty trucks cannot [29,60]. Sripad and Viswanathan [65] 
concluded that the Tesla Semi concept vehicle is technically infeasible given current lithiumion battery technology and is likely financially prohibitive. Tesla CEO Elon Musk stated in early 2021 that production was on hold due to battery cell unavailability and lack of profitability [66].

Batteries have a life span of around 5 to 15 years, creating an additional, significant waste management problem [20]. They cannot be disposed of in landfills due to their toxicity and are one of the fastest-growing contributors to e-waste streams. Only $5 \%$ of all lithium batteries are recycled.

\subsubsection{Problems with Wind Power}

The large metal wind turbines that have become ubiquitous today are composed primarily of steel towers, fiberglass nacelles and blades, and multi-element generators and gearboxes that contain large amounts of steel (iron) and copper. Roughly $25 \%$ of all large wind turbines use permanent magnet synchronous generators (PMSGs) - the latest generation technology that uses the rare earth metals neodymium $(\mathrm{Nd})$, praseodymium (Pr), dysprosium (Dy), and terbium ( $\mathrm{Tb}$ ). The remaining $75 \%$ of operating wind turbines use some form of conventional magnetic generator. Employment of PMSGs is expected to grow given their post-implementation advantages [67].

Steel production is dependent on coal. Steel is an alloy of iron and carbon, the latter contributed by metallurgical, or coking, coal. The production of coke from metallurgical coal requires temperatures around $1800^{\circ} \mathrm{F}\left(1000^{\circ} \mathrm{C}\right)$. Combining coke and iron to make steel then requires blast furnaces at temperatures of $3100^{\circ} \mathrm{F}\left(1700^{\circ} \mathrm{C}\right)$. On average, 1.85 tons of $\mathrm{CO}_{2}$ are emitted for every ton of steel produced [25].

Mining and processing the rare earth metals now common in most wind turbines produces significant toxic waste. Many rare earth metals are bound up in ore deposits that contain thorium and uranium, both of which are radioactive [68]. Sulfuric acid is used to isolate the rare earth metals from the ore, exposing the radioactive residue and producing hydrofluoric acid, sulfur dioxide, and acidic wastewater [68,69]. One ton of radioactive waste is produced for every ton of mined rare earth metals. Rare earth metal processing for wind turbines already generates as much radioactive waste as the nuclear industry [69].

A typical $3 \mathrm{MW}$ wind turbine weighs anywhere from 430 to 1200 tonnes [70]. All components must be transported by large trucks from manufacturing to installation sites and then erected using enormous cranes once on-site. As previously noted, neither heavyduty trucks nor cranes can yet operate on battery power. As shown later, electrified freight on a Paris Agreement schedule ( $50 \%$ emissions reductions by 2030$)$ is improbable, if not impossible.

Massive concrete bases-often requiring more than 1000 tons of concrete and steel rebar and measuring 30 to 50 feet across and anywhere from six to 30 feet deep-are needed to fix the tower to the ground. Heavy-duty fossil powered machinery is required to excavate the site. Cement, which is the primary ingredient in concrete, is produced in industrial kilns heated to $2700{ }^{\circ} \mathrm{F}\left(1500{ }^{\circ} \mathrm{C}\right)$. At least one ton of $\mathrm{CO}_{2}$ is emitted for every ton of cement produced [71], and the cement must then be transported on fossil-fueled trucks to the installation site.

A 3.1 MW wind turbine creates anywhere from 772 to 1807 tons of landfill waste, 40 to 85 tons of waste sent for incineration, and about 7.3 tons of e-waste [20]. Wind turbine blades, made of composite materials, are completely unrecyclable at present [28].

Finally, while superior to solar PV, neither onshore nor offshore wind power has an EROEI >3:1—far less than necessary to sustain modern civilization [52].

\subsubsection{Eco-Impacts of Hydropower}

Large hydroelectric dams have enormous ecological impacts [72]. They disrupt water flow, degrade water quality, block the transport of vital nutrients and sediment, destroy fish and wildlife habitat, impede the migration of fish and other aquatic species, and compromise certain recreational opportunities. Reservoirs slow and broaden rivers, making 
them warmer. Many dams are not operating efficiently, are not up to environmental standards, produce less energy over time, and are in need of significant repairs [73-75].

\subsubsection{Problems with Nuclear}

To meet the anticipated primary energy demand in 2050-assuming 60\% emissions reductions from 2004 levels-approximately 26,000 1-GW nuclear power plants would have to be built. The world currently has 449 , many of which are nearing the end of their lives and will soon face decommissioning [76]. The EROI and materials for facility construction and operation aside, the enormous financial costs, regulatory time frames, social opposition, and waste disposal hurdles make the all-nuclear option a practical impossibility [76].

Only two prototype Generation IV "intrinsically safe" reactors have been built, one in China and one in Russia, with significant R\&D remaining and commercialization forecasted to be two to three decades out [77]. Even though Generation IV reactors use fuel more efficiently and can even use some nuclear waste, claims about greatly reduced radioactive waste are misleading [78]. The narrow focus on reduced actinides is irrelevant since it is other fission byproducts that are of the greatest concern for long-term safety. Moreover, the fuel retreatment process to reduce actinide quantities relies on exceptional technological requirements and itself generates waste that must be disposed of.

Small modular reactors (SMRs) would offer the benefits of a smaller size and transportability but are still in the R\&D phase and pose two major problems [79]. Just as with large wind turbines, SMRs need to be transported long distances, which is not possible without large fossil-fueled trucks and cranes. Additionally, SMRs still produce the same radioactive waste products that large reactors do [80].

The holy grail of nuclear fusion continues to be plagued by problems [81]. To replicate fusion here on Earth, temperatures of at least 100 million degrees Celsius-about six times hotter than the sun-would be needed. Deuterium and tritium, the fuels available for Earth-bound fusion, are 24 orders of magnitude more reactive than the ordinary hydrogen burned by the sun, implying a billion times lower particle density and a trillion times poorer energy confinement. In Earth-bound fusion, energetic neutron streams comprise $80 \%$ of the energy output of deuterium-tritium reactions (the only potentially feasible reaction type). These neutron streams lead to four problems with fusion energy: radiation damage to structures, radioactive waste, the need for biological shielding, and the potential for the production of weapons-grade plutonium. Fusion reactors would share other serious problems that plague fission reactors: daunting water demands for cooling; parasitic power drains that make it uneconomic to run a fusion plant below $1000 \mathrm{MW}$; the release of biologically hazardous, radioactive tritium into the environment; and high operating costs. Additionally, they require a fuel (tritium) that is not found in Nature and is generated only by fission reactors.

Nuclear power plants cannot be built without large fossil-fueled cranes and enormous amounts of concrete, the production of which, as noted, emits a significant amount of $\mathrm{CO}_{2}$ and requires high temperatures that cannot currently be generated without FFs.

\subsubsection{Metal Extraction and Its Social Injustices}

A shift to the RE technologies covered here would simply increase society's dependence on non-renewable resources-not just FFs but also more metals and minerals, adding massive exploitation of the geosphere to the existing over-exploitation of the atmosphere [17]. The demand for minerals is expected to rise substantially through 2050. Hund et al. [18] project increases of up to 500\% from 2018 production levels, particularly for those used in energy storage (e.g., lithium, graphite, and cobalt), and a recent International Energy Agency (IEA) [82] report estimates that reaching "net zero" globally by 2050 would require six times the amount of mineral resources used today. This would entail a quantity of metal production-requiring considerable FF combustion-over the next 15 years roughly equal to that from the start of humanity until 2013 [17]. 
The explosion in demand is already underway. Michaux [19] shows that the production/consumption of industrial minerals increased by 144\% between 2000 and 2018; precious metal consumption is up by $40 \%$ and base metal consumption by $96 \%$. However, both the rate of mineral discovery and the grade of processed ores are well into decline. Michaux concludes that "global reserves are not large enough to supply enough metals to build the renewable non-fossil fuels industrial system or satisfy long term demand in the current system". Clearly, without extraordinary advances in mining and refining technology, the $10 \%$ of world energy consumption currently used for mineral extraction and processing would rise as poorer and more remote deposits are tapped [17].

Social injustices abound in the production of current so-called RE technologies, confounding demands for social justice in the energy transition. Much of the mining and refining of the material building blocks of so-called renewables takes place in developing countries and contributes to environmental destruction, air pollution, water contamination, and risk of cancer and birth defects [20]. Low-paid labor is often the norm, as is gender inequality and the subjugation and exploitation of ethnic minorities and refugees [20]. Mining often relies on the exploitation of children, some of whom are exposed to risks of death and injury, are worked to death in e-waste scrapyards, or drown in waterlogged pits [20]. Land grabs and other forms of conflict and violence are routinely linked to climate change mitigation efforts around the world [21]. In short, while so-called RE technologies may deliver cleaner point-of-use conditions in the Global North, substantial ecological costs and social damage have been displaced to the Global South [20]. As the push for "green" energy and technology intensifies, such harms are increasingly spilling over into North America and Europe [21].

\subsubsection{Problems with Technological Carbon Sequestration}

Carbon capture and storage (CCS) and direct air capture (DAC) are widely advanced as mechanisms for removing carbon. Like all other so-called RE technologies, both carry hidden costs and problems. CCS presupposes the continued use of FFs, which is problematic given FFs' rapidly declining EROI and environmental and human health concerns. Both CCS and DAC pose energetic, ecological, resource, and financial problems. Over their life cycles, some technologies emit more $\mathrm{CO}_{2}$ than they capture [83]. It would cost around $\$ 600$ billion to capture and sequester $1 \mathrm{Gt}$ of carbon [84]. The largest DAC facility in the world captures only $4000 \mathrm{t} \mathrm{CO}_{2}$ per year, which is $0.000004 \mathrm{Gt}$ [83]. A larger plant is now being engineered but will still capture only one $\mathrm{Mt}(0.001 \mathrm{Gt})$ of $\mathrm{CO}_{2}$ annually [85]. These quantities are minuscule in comparison to what is needed: the world emitted roughly $38 \mathrm{Gt} \mathrm{CO}_{2}$ in 2019 [86]. Vast quantities of natural resources and land would be needed to scale up such operations. "Renewably" powered DAC alone would use all wind and solar energy generated in the United States in 2018 - and this would capture only one-tenth of a Gt of $\mathrm{CO}_{2}$ [83]. Advocates of CCS and DAC also largely ignore their ecological impacts, including the transportation, injection, and storage of $\mathrm{CO}_{2}$ in the Earth, as well as potential groundwater contamination, earthquakes, and fugitive emissions.

\subsubsection{Hidden Fossil Fuel Subsidy}

Every so-called RE technology today is subsidized by FFs throughout its entire life cycle. The metals and other raw materials are mined and processed using petroleum-fueled, large-scale machinery. These metals and raw materials are transported around the world on cargo ships that burn bunker fuel and on trucks that are powered by diesel and travel on roads constructed with FFs. Manufacturing processes use very high temperatures that can only be generated reliably and at scale from FFs. Finished products are transported from manufacturing to installation sites on trucks powered by diesel and, in the case of industrial-scale wind turbines, nuclear facilities, and hydroelectric dams, erected on-site with large petroleum-fueled machinery. At the end of their lives, they are then deconstructed, oftentimes with FFs, and transported to landfills or recycling facilities on large petroleum-fueled trucks. There is no possibility that all these FF-demanding processes 
can be replaced by renewable electricity in the foreseeable future, let alone on a schedule consistent with the Paris Agreement.

\subsubsection{Performance Gains in Energy Extraction}

Moore's Law, which states that the number of transistors on a microprocessor chip will double every two years or so, has driven the information technology revolution for 60 years. This accounts for the billion-fold exponential increase in the efficiency of microchips in storing and processing information.

Moore's Law is sometimes used to assure society that there can be equivalent exponential increases in future renewable energy output [32]. Regrettably, the analogy does not hold-Moore's law is irrelevant to the physics of energy systems. Combustion engines are subject to the Carnot Efficiency Limit, solar cells are subject to the Shockley-Queisser Limit, and wind turbines are subject to the Betz Limit. Bound by the Shockley-Queisser Limit, a conventional, single-junction PV cell can convert a maximum of only about 33\% of incoming solar energy into electricity (multi-layered solar cells could theoretically double this efficiency but can be orders of magnitude more expensive; useful in space exploration, they are impractical for large-scale terrestrial applications) $[87,88]$. State-of-the-art commercial PVs achieve just over $26 \%$ conversion efficiency-close to their theoretical efficiency limit. The Betz Limit states that the theoretical maximum efficiency of a wind turbine is just over 59\%, meaning that blades can convert at most this amount of the kinetic energy in wind into electricity $[89,90]$. Turbines today exceed $45 \%$ efficiency, again making additional gains difficult to achieve.

Starry-eyed optimists who argue that the amount of solar radiation that reaches the Earth's surface far exceeds global energy consumption confuse total energy flow with practical harvestability and thus generally ignore the limiting laws of physics.

\subsubsection{The Liquid Fuels Question}

Liquid fuels currently account for $81 \%$ of non-electric global energy consumption. It is highly unlikely that synthetic liquid fuel substitutes for FFs can be produced sustainably in any more than small quantities for niche applications. This is highly problematic, as modern urban civilization is dependent on highway transportation for essential supplies. As noted above, battery-powered cars and, in particular, trucks have serious limitations and raise many questions regarding resource use and manufacturing. We must also ask how asphalt roads and highways - made of petroleum-based products and laid with heavy machinery-will be maintained and built in the future. Like the bright green dream of electrified transportation, synthetic substitutes for liquid FFs pose myriad problems.

\subsubsection{Biofuels vs. Food Production}

The current population-and projected growing populations-can only be fed by using an array of fossil-fueled subsidies. The FF-based synthetic pesticides, herbicides, and fungicides, not to mention the petroleum-fueled heavy machinery, responsible for The Green Revolution have allowed for much higher agricultural outputs per unit of land area - at great ecological cost - than was previously attainable. Today's global food distribution system also relies on liquid-fossil-powered transportation and refrigeration systems. Clearly, removing FFs from the agricultural system would result in significantly reduced output. Even if a global one-child policy were enacted soon, we would still have eight to 3.5 billion mouths to feed by the end of the century [91]. Even under such an optimistic scenario, virtually every square inch of arable land would have to be dedicated to food production. This would ethically prohibit the widescale production of fuels like bioethanol and biodiesel. (It is scandalous that $40 \%$ of the U.S. corn crop is dedicated to heavily subsidized, carbon-emitting ethanol production, with virtually no net energy gains over the history of its production [92,93]). The delay in enacting, or the absolute failure to enact, fertility reduction policies, particularly in high-fertility countries, raises the specter of an even more dire scenario. 


\subsubsection{The Pipedream of Other Synthetic Fuels}

Algae is not a solution to our liquid fuel needs [29]. More energy is consumed to cultivate the algae than it usefully generates. Major technical difficulties still need to be overcome despite 60 years of research. Protozoans that invade a pond can eat all the algae within 12-18 h. The National Research Council concluded that scaling up algal biofuel production to replace even $5 \%$ of U.S. transportation fuel would place unsustainable demands on energy, water, and nutrients. The U.S. Department of Energy found that "systems for large-scale production of biofuels from algae must be developed on scales that are orders of magnitude larger than all current world-wide algal culturing facilities combined".

Nor is synthetic hydrogen an option. As discussed earlier, hydrogen is also a net energy sink and is extremely difficult to transport and store.

\subsubsection{Electrification of Transportation}

Electrifying the rail freight system seems improbable [29]. The current U.S. fleet of 25,000 mostly diesel-electric locomotives would use as much grid electricity as 55 million electric cars. Electrifying major routes (160,000 of the 200,000 miles of tracks) would require the energy equivalent of that generated by 240 power plants (keeping in mind, too, that railway load is one of the most difficult for an electric utility to cope with). It would also require a national grid—which does not yet exist—or at least a much-expanded grid.

An all-electric passenger rail system is equally improbable. Just as with freight, it would require an expanded grid. Passenger trains are highly inefficient due to the constant stopping and accelerating [94] and are extremely costly. California's planned high-speed rail connecting the length of the state was originally estimated to cost $\$ 33$ billion but, by 2019 , the price tag had ballooned to $\$ 79$ billion. Annual operation and maintenance costs are currently pegged at $\$ 228$ million [95].

With accelerating climate change, possible food shortages, no viable alternatives to FFs, and the time when "the trucks stop running" not far off [29], the prospects for our globalized, transport-based, just-in-time urbanized civilization are dire [96].

\section{Summary and What Might Actually Salvage Civilization}

We have exposed fatal weaknesses in society's dominant aspirational pathway for combating climate change. The GND illusion paints a picture of "affordable clean energy" that ignores innumerable costs that cannot be afforded by any reasonable measure. It suggests solutions to the climate-energy conundrum that are impossible to deliver with current technologies, and certainly not within the timeframe specified by the IPCC and Paris Agreement.

Not only is the GND technically flawed, but it fails to situate climate disruption within the broader context of ecological overshoot. Anthropogenic climate change is merely one symptom of overshoot and cannot be treated in isolation from the greater disease. The GND offers little more than a green-washed version of the unsustainable growth-based status quo. Even if feasible, its operationalization would only exacerbate human ecological dysfunction.

What, then, might actually salvage a fossil-dependent world in overshoot? The answer is both stunningly simple and wretchedly complex: the world must abandon neoliberal capitalism's material growth imperative and face head-on that material life after fossil fuels will closely resemble life before fossil fuels. Put another way, we must act on the ecological imperative to achieve one-Earth living. This entails moving on three broad fronts.

\subsection{Energy Realism}

First, we must relinquish our faith in modern high technology and instead shift our attention to understanding what a genuinely renewable energy landscape will look like. As noted, the so-called RE technologies being advanced as solutions are neither renewable nor possible to construct and implement in the absence of FFs. They are not carbon 
neutral and will simply increase human dependence on non-renewable resources and cause unacceptable social and environmental harm.

Truly renewable energy sources will be largely based on biomass (especially wood), simple mechanical wind and water generation, passive solar, and animal and human labor. This means society will have to innovate and adapt its way through major reductions in energy supply. The upside is that new variants on old extraction technologies will be more ecologically sophisticated than today's so-called renewables, closely tuned to essential needs, and cognizant of the conservation imperative. On this latter point, it is important to highlight that approximately $62 \%$ of energy flow through the modern economy is wasted through inefficiency [97], and more still is wasted through trivial or at least non-essential uses (think leaf-blowers and recreational ATVs). Globally, per capita energy consumption has increased nine-fold since 1850, though perceived well-being certainly has not. Together, these facts show there is much latitude for painless reductions in energy use.

A reduction in energy means there will be a resurgence in demand for human muscle and draft animals. Denizens of FF-rich societies tend to forget that that industrial energy now does the work that people and animals used to do. How many Americans are conscious of the fact that they have hundreds of "energy slaves", per capita, in continuous employment to provide them with goods and services they have come to take for granted? According to Hagens and White [98], if we ignore nuclear and hydropower electricity, " $99.5 \%$ of 'labor' in human economies is done by oil, coal, and natural gas" (for a summary of the energy slave concept and various definitions, see [99]). It is again important to highlight the silver lining accompanying this shift. More human labor will mean more physically active lives in closer contact with each other and Nature, which can restore our shattered sense of well-being and connection to the land. Similarly, a waning focus on material progress will allow for emphasis to shift to progress of the mind and spirit-largely untapped frontiers at present with unlimited potential.

On the draft animal side, the number of working horses and mules in the United States peaked at 26 million around 1915 - when the human population was about 100 milliononly to be gradually replaced by fossil-powered farm and industrial equipment [100]. Should the United States again become as dependent on animal labor, the country may once more need this many draft animals if the population shrinks to 100 million. If human numbers remain in the vicinity of 2021's population of 333 million, the required horse/mule population might be as high as 87 million and require around 172 million acres of land for range and fodder production (note that of the five to 10 million horses in the United States today, only about $15 \%$ are working farm or ranch animals [100]).

\subsection{Population Reduction}

The second front in a one-Earth living strategy is a global one-child fertility standard. This is needed to reduce the global population to the one billion or so people that can thrive sustainably in reasonable material comfort within the constraints of a non-fossil energy future and already much damaged Earth [101,102]. Even a step as seemingly bold as this may be insufficient to avoid widespread suffering, as such a policy implemented within a decade or two would still leave us with about three billion souls by the end of the century [91]. Failure to implement a planned, relatively painless population reduction strategy would guarantee a traumatic population crash imposed by Nature in a climate-ravaged, fossilenergy-devoid world. (A human population crash imposed by a human-compromised environment (not Nature) may already be underway. Controversial studies have documented evidence of falling sperm counts $(50 \%+)$ and other symptoms of the feminization of males, particularly in western countries, caused by female-hormone-mimicking industrial chemicals; see, for example, [103]).

Concerns over the restriction of procreative freedom, racism, and physical coercion that dominate much of the present discourse on population reduction must be put into perspective. Population is an ecological issue that, if left unchecked, can have catastrophic consequences. The human population growth curve over the past 200 years resembles the 
boom, or "plague", phase of the kind of population outbreak that occurs in non-human species under unusually favorable ecological conditions (in our case, the resource bounty made available by abundant cheap energy). Plague outbreaks invariably end in collapse under the pressure of social stress or as crucial resources are depleted [104].

Previous cultures have recognized this fact, along with the need for population regulation, for thousands of years $[105,106]$. A judicious balance between the freedom and well-being of individuals and society involves knowing when to arc nimbly between these poles as circumstances change. There is perhaps no greater rallying cry for the restriction of certain individual freedoms than the imminent threat of global social-ecological collapse.

Though it hardly seems worth stating, a universal one-child policy applied globally is not discriminatory. Moreover, it is entirely justified when the restoration of ecological integrity for the well-being of present and future generations-of humans and non-humans alike-is the motivation. Fortunately, there is a full toolbox of socially just and humane tools for bringing about the necessary population reduction $[107,108]$. That some inhumane practices have been used in particular circumstances historically is no reason to ignore the gravity of contemporary overshoot and the ample mechanisms available for sustainable population planning. When it comes to both the environmental and social aspects of overshoot, no other single individual action comes close to being as negatively consequential as having a child [109].

We should note that the human population at carrying capacity is a manageable variable whose magnitude will depend, in part, on society's preferred material standard of living. This is a finite planet with limited productive capacity. A constant, sustainable rate of energy and material throughput will obviously support fewer people at a high average material standard than it will at a lower material standard.

We cannot stress enough that a non-fossil energy regime simply cannot support anywhere close to the present human population of nearly eight billion; this urgently necessitates reducing human numbers as rapidly as possible to avoid unprecedented levels of social unrest and human suffering in the coming decades. (This flies in the face of mainstream concerns that the falling fertility rate in many (particularly high-income) countries is cause for alarm; see, for example, [110]).

\subsection{Radical Societal Contraction and Transformation}

The third major front of a one-Earth sustainability strategy is a fully transformative plan to reshape the social and economic foundations of society while simultaneously managing a systematic contraction of the human enterprise (the latter to be consistent with Global Footprint Network estimates that humanity is in $75 \%$ overshoot). This is necessitated, in part, by the need to phase out fossil energy within a set time and carbon budget. (The situation is becoming increasingly urgent; Spratt et al. [111] argue that little or no budget exists to remain even within $2{ }^{\circ} \mathrm{C}$ ). Whatever the identified FF budget, it must be rationed and allocated to: (1) essential uses, such as agriculture and essential bulk transportation; and (2) de-commissioning hazardous fossil-based infrastructure and replacing it with renewable-based infrastructure and supply chains.

Other elements of such a plan would include: (3) economic and political restructuring in conformity with the new energy and material realities (e.g., the cessation of interest-bearing debt and possibly even a shift to negative interest; a renewed focus on community building and regional self-reliance; re-localization of essential production and other economic activities; emphasis on economic resilience over mere efficiency; and a down-shifting of control over land and resource use to local self-governing bodies); (4) worker retraining for new forms of work and employment; (5) social planning to ensure a just allocation and distribution of societal resources, as it is inherently unjust for some individuals to appropriate much more than their fair share of the Earth's limited bounty; (6) planned migrations and resettlement from unsustainable dense urban centers and vulnerable coastlines; and (7) large-scale ecosystem restoration. Restoration would serve the multiple purposes of not only creating meaningful employment but also reclaiming 
ecosystem integrity for the benefit of humans and non-humans alike, capturing carbon, increasing social-ecological resilience, and increasing the stock of biomass available for human energy consumption. In many respects, this endeavor will resemble Polanyi's [112] Great Transformation (about the emergent dominance of neoliberal market economics) in reverse, all contained within an envelope of ecological necessity.

Actions to embark swiftly, judiciously, and systematically on the transformation will be of a far greater scale and level of effort than WWII mobilization and will involve unprecedented levels of global cooperation. In our view, two main conditions must be satisfied concurrently for such an undertaking to have any chance of succeeding. First, we must have politicians in office who care about people and the planet (i.e., who are not beholden to corporate, monied, or otherwise compromised interests) and who are willing to fight fiercely for ecological stability and social justice. This starts with whom we choose to elect (politicians do not magically fall into office-we put them there), holding them relentlessly accountable, and fighting to get money out of politics. Second, history shows that monied and ruling elites do not relinquish their power willingly - their hand must be forced. Virtually no important gain has ever been made by simply asking those in power to do the right thing. Unrelenting pressure must be exerted such that the people and/or systems in question have no choice but to capitulate to specific, well-thought-out demands. We must reacquaint ourselves with the revolutionary change-makers of the past who, at great cost, delivered for us the better world we live in now through intelligent, direct action and risk-taking.

To adopt a biblical metaphor, it may very well be easier for a camel to go through the eye of a needle than for humanity to shift its prevailing paradigm and embark on a planned, voluntary descent from a state of overshoot to a steady-state harmonic relationship with the ecosphere-in just a decade or two. On the other hand, history shows that virtually all important achievements have only ever arisen from a dogged pursuit of the seemingly impossible. To contemplate the alternative is unthinkable.

Author Contributions: Writing-original draft preparation, M.K.S.; writing-additional content, W.E.R.; review and editing-M.K.S., W.E.R. All authors have read and agreed to the published version of the manuscript.

Funding: This research received no external funding.

Institutional Review Board Statement: Not applicable.

Informed Consent Statement: Not Applicable.

Conflicts of Interest: The authors declare no conflict of interest.

\section{References}

1. Jacobson, M.Z.; Delucchi, M.A.; Cameron, M.A.; Mathiesen, B.V. Matching Demand with Supply at Low Cost in 139 Countries among 20 World Regions with 100\% Intermittent Wind, Water, and Sunlight (WWS) for All Purposes. Renew. Energy 2018, 123, 236-248. [CrossRef]

2. Williams, J.H.; Jones, R.A.; Haley, B.; Kwok, G.; Hargreaves, J.; Farbes, J.; Torn, M.S. Carbon-Neutral Pathways for the United States. AGU Adv. 2021. [CrossRef]

3. Larson, E.; Greig, C.; Jenkins, J.; Mayfield, E.; Pascale, A.; Zhang, C.; Drossman, J.; Williams, R.; Pacala, S.; Socolow, R.; et al. Net-Zero America: Potential Pathways, Infrastructure, and Impacts, Interim Report; Princeton University: Princeton, NJ, USA, 2020.

4. Bogdanov, D.; Ram, M.; Aghahosseini, A.; Gulagi, A.; Oyewo, A.S.; Child, M.; Caldera, U.; Sadovskaia, K.; Farfan, J.; De Souza Noel Simas Barbosa, L.; et al. Low-Cost Renewable Electricity as the Key Driver of the Global Energy Transition towards Sustainability. Energy 2021, 227, 120467. [CrossRef]

5. Carlock, G.; Mangan, E. A Green New Deal: A Progressive Vision for Environmental Sustainability and Economic Stability. Available online: https:/ / www.dataforprogress.org/green-new-deal-report (accessed on 21 May 2021).

6. House Select Committee on the Climate Crisis. Available online: https:/ / climatecrisis.house.gov (accessed on 21 May 2021).

7. Recognizing the Duty of the Federal Government to Create a Green New Deal, H.R. 109, 116th Congress. 2019. Available online: https: / / www.congress.gov/bill/116th-congress/house-resolution/109/text (accessed on 30 May 2021).

8. Roser, M.; Ritchie, H.; Ortiz-Ospina, E. World Population Growth. Our World in Data. 2013. Available online: https:// ourworldindata.org/world-population-growth\#how-has-world-population-growth-changed-over-time (accessed on 30 May 2021). 
9. Smil, V. Harvesting the Biosphere: The Human Impact. Popul. Dev. Rev. 2011, 37, 613-636. [CrossRef] [PubMed]

10. Smil, V. Harvesting the Biosphere: What We Have Taken from Nature; MIT Press: Cambridge, MA, USA, 2012.

11. Bar-On, Y.M.; Phillips, R.; Milo, R. The Biomass Distribution on Earth. Proc. Natl. Acad. Sci. USA 2018, 115, 6506-6511. [CrossRef] [PubMed]

12. McRae, L.; Deinet, S.; Freeman, R. The Diversity-Weighted Living Planet Index: Controlling for Taxonomic Bias in a Global Biodiversity Indicator. PLoS ONE 2017, 12, e0169156. [CrossRef]

13. Hughes, D. (Global Sustainability Research, Calgary, AB, Canada). Personal communication, 2019.

14. BP. BP Statistical Review of World Energy, 67th ed.; BP: London, UK, 2018.

15. Dukes, J.S. Burning Buried Sunshine: Human Consumption of Ancient Solar Energy. Clim. Chang. 2003, 61, 31-44. [CrossRef]

16. Global Footprint Network. Available online: https://data.footprintnetwork.org/?_ga=2.9934709.1352344526.1610740013-650899 000.1610740013\#/ compareCountries?type $=$ earth\&cn=5001\&yr=2017 (accessed on 21 May 2021).

17. Vidal, O.; Goffé, B.; Arndt, N. Metals for a Low-Carbon Society. Nat. Geosci. 2013, 6, 894-896. [CrossRef]

18. Hund, K.; LaPorta, D.; Fabregas, T.; Laing, T.; Drexhage, J. Minerals for Climate Action: The Mineral Intensity of the Clean Energy Transition; The World Bank Group, Climate-Smart Mining Initiative: Washington, DC, USA, 2020.

19. Michaux, S.P. The Mining of Minerals and the Limits to Growth; Geological Survey of Finland: Espoo, Finland, 2021.

20. Sovacool, B.K.; Hook, A.; Martiskainen, M.; Brock, A.; Turnheim, B. The Decarbonisation Divide: Contextualizing Landscapes of Low-Carbon Exploitation and Toxicity in Africa. Glob. Environ. Chang. 2020, 60, 102028. [CrossRef]

21. Sovacool, B.K. Who Are the Victims of Low-Carbon Transitions? Towards a Political Ecology of Climate Change Mitigation. Energy Res. Soc. Sci. 2021, 73, 101916. [CrossRef]

22. Friedmann, J.; Zhiyuan, F.; Tang, K. Low-Carbon Heat Solutions for Heavy Industry: Sources, Options, and Costs Today; Columbia Center on Global Energy Policy: New York, NY, USA, 2019.

23. Lovegrove, K.; Alexander, D.; Bader, R.; Edwards, S.; Lord, M.; Mojiri, A.; Rutovitz, J.; Saddler, H.; Stanley, C.; Urkalan, K.; et al. Renewable Energy Options for Industrial Process Heat; ITP Thermal/Australian Renewable Energy Agency (ARENA): Turner, Australia, 2019.

24. McMillan, C.; Boardman, R.; McKellar, M.; Sabharwall, P.; Ruth, M.; Bragg-Sitton, S. Generation and Use of Thermal Energy in the U.S. Industrial Sector and Opportunities to Reduce its Carbon Emissions; Joint Institute for Strategic Energy Analysis: Golden, CO, USA, 2016.

25. Sandalow, D.; Friedmann, J.; Aines, R.; McCormick, C.; McCoy, S.; Stolaroff, J. ICEF Industrial Heat Decarbonization Roadmap; Innovation for Cool Earth Forum: Tokyo, Japan, 2019. Available online: https://www.icef-forum.org/pdf/2019/roadmap/ICEF_ Roadmap_201912.pdf (accessed on 26 May 2021).

26. Chowdhury, M.S.; Rahman, K.S.; Chowdhury, T.; Nuthammachot, N.; Techato, K.; Akhtaruzzaman, M.; Tiong, S.K.; Sopian, K.; Amin, N. An Overview of Solar Photovoltaic Panels' End-of-Life Material Recycling. Energy Strategy Rev. 2020, $27,100431$. [CrossRef]

27. Xu, Y.; Li, J.; Tan, Q.; Peters, A.L.; Yang, C. Global Status of Recycling Waste Solar Panels: A Review. Waste Manag. 2018, 75, 450-458. [CrossRef] [PubMed]

28. Liu, P.; Barlow, C.Y. Wind Turbine Blade Waste in 2050. Waste Manag. 2017, 62, 229-240. [CrossRef] [PubMed]

29. Friedemann, A.J. When Trucks Stop Running; SpringerBriefs in Energy; Springer International Publishing: Cham, Switzerland, 2016; ISBN 9783319263731.

30. Moore, J.; Rees, W.E. Getting to One-Planet Living. In State of the World 2013: Is Sustainability Still Possible? Island Press/Center for Resource Economics: Washington, DC, USA, 2013; pp. 39-50, ISBN 9781610914581.

31. International Energy Agency. World Total Final Consumption (TFC) by Source. Available online: https://www.iea.org/reports/ key-world-energy-statistics-2020/final-consumption (accessed on 26 May 2021).

32. Mills, M. The "New Energy Economy": An Exercise in Magical Thinking; The Manhattan Institute: New York, NY, USA, 2019.

33. Zehner, O. Green Illusions: The Dirty Secrets of Clean Energy and the Future of Environmentalism; Our sustainable future; University of Nebraska Press: Lincoln, NE, USA, 2012; ISBN 9780803237759.

34. University of California Berkeley, Goldman School of Public Policy. The 2035 Report: Plummeting Solar, Wind, And Battery Costs Can Accelerate Our Clean Electricity Future. 2020. Available online: http://www.2035report.com/wp-content/uploads/2020 /06/2035-Report.pdf?hsCtaTracking=8a85e9ea-4ed3-4ec0-b4c6-906934306ddb\%7Cc68c2ac2-1db0-4d1c-82a1-65ef4daaf6c1 (accessed on 26 May 2021).

35. Wesoff, E. The US Added 13.3 GW of Solar in 2019, Beating New Wind and Gas Capacity. PV Magazine, 18 March 2020. Available online: https: / / www.pv-magazine.com/2020/03/18/the-us-added-13-3-gw-of-solar-in-2019-beating-wind-and-gas-in-newcapacity /\#: \{\{\}:text=2020,The\%20US\%20added\%2013.3\%20GW\%20of\%20solar\%20in\%202019,\%20beating,capacity\%20now\% 20tops\%2076\%20GW (accessed on 26 May 2021).

36. Clack, C.T.M.; Qvist, S.A.; Apt, J.; Bazilian, M.; Brandt, A.R.; Caldeira, K.; Davis, S.J.; Diakov, V.; Handschy, M.A.; Hines, P.D.H.; et al. Evaluation of a Proposal for Reliable Low-Cost Grid Power with 100\% Wind, Water, and Solar. Proc. Natl. Acad. Sci. USA 2017, 114, 6722-6727. [CrossRef]

37. U.S. Environmental Protection Agency. Renewable Industrial Process Heat. Available online: https://www.epa.gov/rhc/ renewable-industrial-process-heat (accessed on 21 May 2021). 
38. U.S. Energy Information Administration. Use of Energy Explained: Energy Use in Industry. Available online: https://www.eia. gov/energyexplained/use-of-energy/industry.php (accessed on 21 May 2021).

39. International Energy Agency. Report Extract: An Introduction to Biogas and Biomethane. Available online: https://www.iea.org/ reports/outlook-for-biogas-and-biomethane-prospects-for-organic-growth/an-introduction-to-biogas-and-biomethane (accessed on 26 May 2021).

40. Adnan, A.I.; Ong, M.Y.; Nomanbhay, S.; Chew, K.W.; Show, P.L. Technologies for Biogas Upgrading to Biomethane: A Review. Bioengineering 2019, 6, 92. [CrossRef]

41. Lozanovski, A.; Lindner, J.P.; Bos, U. Environmental Evaluation and Comparison of Selected Industrial Scale Biomethane Production Facilities across Europe. Int. J. Life Cycle Assess 2014, 19, 1823-1832. [CrossRef]

42. Angelidaki, I.; Treu, L.; Tsapekos, P.; Luo, G.; Campanaro, S.; Wenzel, H.; Kougias, P.G. Biogas Upgrading and Utilization: Current Status and Perspectives. Biotechnol. Adv. 2018, 36, 452-466. [CrossRef]

43. Koonaphapdeelert, S.; Aggarangsi, P.; Moran, J. Biomethane: Production and Applications; Green Energy and Technology; Springer: Singapore, 2020; ISBN 9789811383069.

44. Ahlström, J.M.; Zetterholm, J.; Pettersson, K.; Harvey, S.; Wetterlund, E. Economic Potential for Substitution of Fossil Fuels with Liquefied Biomethane in Swedish Iron and Steel Industry-Synergy and Competition with Other Sectors. Energy Convers. Manag. 2020, 209, 112641. [CrossRef]

45. Turiel, A. Hydrogen Fever 2.0 (I). The Oil Crash, 17 November 2020. Available online: https://crashoil.blogspot.com/2020/11/ la-fiebre-del-hidrogeno-20-i.html (accessed on 31 June 2021).

46. Nature Needs Half. Available online: https:/ / natureneedshalf.org (accessed on 16 June 2021).

47. Mulvaney, D. Solar Energy Isn't Always as Green As You Think. IEEE Spectrum, 13 November 2014. Available online: https:/ / spectrum.ieee.org/green-tech/solar/solar-energy-isnt-always-as-green-as-you-think (accessed on 26 May 2021).

48. De Wild-Scholten, M.J.; Alsema, E.A. Environmental life cycle inventory of crystalline silicon photovoltaic module production. In Proceedings of the Materials Research Society Fall 2005 Meeting, Boston, MA, USA, 28 November-2 December 2005.

49. Sisodia, A.K.; Mathur, R.K. Impact of Bird Dropping Deposition on Solar Photovoltaic Module Performance: A Systematic Study in Western Rajasthan. Environ. Sci. Pollut. Res. 2019, 26, 31119-31132. [CrossRef]

50. Adinoyi, M.J.; Said, S.A.M. Effect of Dust Accumulation on the Power Outputs of Solar Photovoltaic Modules. Renew. Energy 2013, 60, 633-636. [CrossRef]

51. International Renewable Energy Agency, Photovoltaic Power Systems Programme. End-of-Life Management: Solar Photovoltaic Panels. 2016. Available online: https:/ / www.irena.org/publications/2016/Jun/End-of-life-management-Solar-PhotovoltaicPanels (accessed on 26 May 2021).

52. De Castro, C.; Capellán-Pérez, I. Standard, Point of Use, and Extended Energy Return on Energy Invested (EROI) from Comprehensive Material Requirements of Present Global Wind, Solar, and Hydro Power Technologies. Energies 2020, 13, 3036. [CrossRef]

53. Capellán-Pérez, I.; de Castro, C.; Miguel González, L.J. Dynamic Energy Return on Energy Investment (EROI) and Material Requirements in Scenarios of Global Transition to Renewable Energies. Energy Strategy Rev. 2019, 26, 100399. [CrossRef]

54. Ferroni, F.; Guekos, A.; Hopkirk, R.J. Further Considerations to: Energy Return on Energy Invested (ERoEI) for Photovoltaic Solar Systems in Regions of Moderate Insolation. Energy Policy 2017, 107, 498-505. [CrossRef]

55. Prieto, P.A.; Hall, C.A.S. Spain's Photovoltaic Revolution: The Energy Return on Investment; SpringerBriefs in Energy; Energy Analysis; Springer: New York, NY, USA, 2013; ISBN 9781441994363.

56. University of Michigan, Center for Sustainable Systems. U.S. Energy Storage Factsheet. Pub. No. CSS15-17. University of Michigan, 2020. Available online: http:/ / css.umich.edu/factsheets/us-grid-energy-storage-factsheet (accessed on 26 May 2021).

57. Elmegaard, B.; Brix, W. Efficiency of Compressed Air Energy Storage. In Proceedings of the 24th International Conference on Efficiency, Cost, Optimization, Simulation and Environmental Impact of Energy Systems, Novi Sad, Serbia, 4-7 July 2011.

58. U.S. Energy Information Administration. Most Utility-Scale Batteries in the United States Are Made of Lithium-Ion. 2019. Available online: https:/ / www.eia.gov/todayinenergy/detail.php?id=41813 (accessed on 21 May 2021).

59. Global Energy Statistical Yearbook 2020. Electricity Domestic Consumption. Available online: https://yearbook.enerdata.net/ electricity / electricity-domestic-consumption-data.html (accessed on 21 May 2021).

60. Smil, V. Electric Container Ships Are Stuck on the Horizon: Batteries still can't Scale Up to Power the World's Biggest Vessels. IEEE Spectrum, 27 February 2019. Available online: https://spectrum.ieee.org/transportation/marine/electric-container-shipsare-stuck-on-the-horizon (accessed on 26 May 2021).

61. Deng, J.; Bae, C.; Denlinger, A.; Miller, T. Electric Vehicles Batteries: Requirements and Challenges. Joule 2020, 4, 511-515. [CrossRef]

62. Battery University. Batteries against Fossil Fuel. Available online: https://batteryuniversity.com/learn/archive/batteries_ against_fossil_fuel (accessed on 21 May 2021).

63. Qiao, Q.; Zhao, F.; Liu, Z.; Jiang, S.; Hao, H. Cradle-to-Gate Greenhouse Gas Emissions of Battery Electric and Internal Combustion Engine Vehicles in China. Appl. Energy 2017, 204, 1399-1411. [CrossRef]

64. Liebherr. LR 1200.1 Unplugged. Available online: https://www.liebherr.com/en/usa/products/mobile-and-crawler-cranes/ crawler-cranes/lr-crawler-cranes/details/lr1200unplugged.html (accessed on 21 May 2021). 
65. Sripad, S.; Viswanathan, V. Performance Metrics Required of Next-Generation Batteries to Make a Practical Electric Semi Truck. ACS Energy Lett. 2017, 2, 1669-1673. [CrossRef]

66. Etherington, D. Elon Musk Says Tesla Semi Is Ready for Production, but Limited by Battery Cell Output. TechCrunch, 27 January 2021. Available online: https://techcrunch.com/2021/01/27/elon-musk-says-tesla-semi-is-ready-for-production-but-limitedby-battery-cell-output/ (accessed on 26 May 2021).

67. Pavel, C.C.; Lacal-Arántegui, R.; Marmier, A.; Schüler, D.; Tzimas, E.; Buchert, M.; Jenseit, W.; Blagoeva, D. Substitution Strategies for Reducing the Use of Rare Earths in Wind Turbines. Resour. Policy 2017, 52, 349-357. [CrossRef]

68. Law, Y. Radioactive Waste Standoff Could Slash High Tech's Supply of Rare Earth Elements. Science, 1 April 2019. Available online: https:// www.sciencemag.org/news/2019/04/radioactive-waste-standoff-could-slash-high-tech-s-supply-rare-earthelements (accessed on 26 May 2021).

69. Fisher, T.; Fitzsimmons, A. Big Wind's Dirty Little Secret: Toxic Lakes and Radioactive Waste. Institute for Energy Research, 23 October 2013. Available online: https:/ / www.instituteforenergyresearch.org/renewable/wind/big-winds-dirty-little-secretrare-earth-minerals/ (accessed on 26 May 2021).

70. Wind-Turbine-Models.com. Turbines. Available online: https://en.wind-turbine-models.com/turbines (accessed on 21 May 2021).

71. Hanle, L.J.; Jayaraman, K.R.; Smith, J.S. $\mathrm{CO}_{2}$ Emissions Profile of the U.S. Cement Industry. Available online: https:/ /www3.epa. gov/ttnchie1/conference/ei13/ghg/hanle.pdf (accessed on 26 May 2021).

72. Schmutz, S.; Moog, O. Dams: Ecological Impacts and Management. In Riverine Ecosystem Management: Science for Governing Towards a Sustainable Future; Schmutz, S., Sendzimir, J., Eds.; Aquatic Ecology Series; Springer International Publishing: Cham, Switzerland, 2018; pp. 111-127, ISBN 9783319732503.

73. Moriarty, P.; Honnery, D. Can Renewable Energy Power the Future? Energy Policy 2016, 93, 3-7. [CrossRef]

74. Warner, K.; Pejchar, L. A River Might Run Through It Again: Criteria for Consideration of Dam Removal and Interim Lessons from California. Environ. Manag. 2001, 28, 561-575. [CrossRef]

75. Zamarrón-Mieza, I.; Yepes, V.; Moreno-Jiménez, J.M. A Systematic Review of Application of Multi-Criteria Decision Analysis for Aging-Dam Management. J. Clean. Prod. 2017, 147, 217-230. [CrossRef]

76. Alexander, S.; Floyd, J. Carbon Civilisation and the Energy Descent Future: Life Beyond this Brief Anomaly; The Simplicity Institute/The Rescope Project: Melbourne, Australia, 2018; ISBN 9780994282804.

77. GenIV International Forum. When Will GenIV Reactors Be Built? Available online: https://www.gen-4.org/gif/jcms/c_41890/ faq-2 (accessed on 21 May 2021).

78. Krall, L.; Macfarlane, A. Burning Waste or Playing with Fire? Waste Management Considerations for Non-Traditional Reactors. Bull. At. Sci. 2018, 74, 326-334. [CrossRef]

79. Cho, A. Smaller, Safer, Cheaper: One Company Aims to Reinvent the Nuclear Reactor and Save a Warming Planet. Science, 21 February 2019. Available online: https:/ /www.sciencemag.org/news/2019/02/smaller-safer-cheaper-one-company-aimsreinvent-nuclear-reactor-and-save-warming-planet (accessed on 26 May 2021).

80. Chatzis, I. Small Modular Reactors: A Challenge for Spent Fuel Management? International Atomic Energy Agency, 8 August 2019. Available online: https://www.iaea.org/newscenter/news/small-modular-reactors-a-challenge-for-spent-fuel-management (accessed on 26 May 2021).

81. Jassby, D. Fusion Reactors: Not What They're Cracked Up to Be. Bulletin of the Atomic Scientists, 19 April 2017. Available online: https: / / thebulletin.org/2017/04/fusion-reactors-not-what-theyre-cracked-up-to-be/ (accessed on 26 May 2021).

82. International Energy Agency. The Role of Critical Minerals in Clean Energy Transitions. 2021. Available online: https://www.iea. org/reports/the-role-of-critical-minerals-in-clean-energy-transitions (accessed on 26 May 2021).

83. Sekera, J.; Lichtenberger, A. Assessing Carbon Capture: Public Policy, Science, and Societal Need. Biophys. Econ. Sust. 2020, 5, 14. [CrossRef]

84. Service, F. Cost Plunges for Capturing Carbon Dioxide from the Air. Science, 7 June 2018. Available online: https://www. sciencemag.org/news/2018/06/cost-plunges-capturing-carbon-dioxide-air (accessed on 26 May 2021).

85. Carbon Engineering. Available online: https:/ / carbonengineering.com/ (accessed on 7 May 2021).

86. United Nations Environment Programme. Emissions Gap Report 2020. 2020. Available online: https:/ /www.unep.org/emissionsgap-report-2020 (accessed on 15 June 2021).

87. Vossier, A.; Gualdi, F.; Dollet, A.; Ares, R.; Aimez, V. Approaching the Shockley-Queisser Limit: General Assessment of the Main Limiting Mechanisms in Photovoltaic Cells. J. Appl. Phys. 2015, 117, 015102. [CrossRef]

88. Ehrler, B.; Alarcón-Lladó, E.; Tabernig, S.W.; Veeken, T.; Garnett, E.C.; Polman, A. Photovoltaics Reaching for the ShockleyQueisser Limit. ACS Energy Lett. 2020, 5, 3029-3033. [CrossRef]

89. Jiang, H.; Li, Y.; Cheng, Z. Performances of Ideal Wind Turbine. Renew. Energy 2015, 83, 658-662. [CrossRef]

90. De Lellis, M.; Reginatto, R.; Saraiva, R.; Trofino, A. The Betz Limit Applied to Airborne Wind Energy. Renew. Energy 2018, 127, 32-40. [CrossRef]

91. Bradshaw, C.J.A.; Brook, B.W. Human Population Reduction Is Not a Quick Fix for Environmental Problems. Proc. Natl. Acad. Sci. USA 2014, 111, 16610-16615. [CrossRef] [PubMed]

92. Patzek, T.W. Thermodynamics of the Corn-Ethanol Biofuel Cycle. Crit. Rev. Plant Sci. 2004, 23, 519-567. [CrossRef] 
93. Gallagher, P.; Yee, W.; Baumes, H. 2015 Energy Balance for the Corn-Ethanol Industry; Economics Technical Reports and White Papers; Iowa State University: Ames, IA, USA, 2016.

94. Friedemann, A. Why Is Passenger Rail So Damned Inefficient? Energy Skeptic. 10 October 2016. Available online: http: / / energyskeptic.com/2016/why-is-passenger-rail-so-damned-inefficient/ (accessed on 27 May 2021).

95. Friedemann, A. Will California's High-Speed Rail Go Off the Tracks? Energy Skeptic. 9 May 2019. Available online: http: / / energyskeptic.com/2019/challenges-facing-californias-high-speed-rail-house-hearing-2014/ (accessed on 27 May 2021).

96. Rees, W.E. Megacities at risk: The climate-energy conundrum. In Handbook of Megacities and Megacity-Regions; Labbé, D., Sorenson, A., Eds.; Edward Elgar Publishing: Cheltenham, UK, 2020; pp. 292-308, ISBN 9781788972703.

97. Lawrence Livermore National Laboratory. Estimated U.S. Energy Consumption in 2020: 92.9 Quads. Available online: https: / / flowcharts.llnl.gov/content/assets/images/energy/us/Energy_US_2020.png (accessed on 27 May 2021).

98. Hagens, N.; White, D.J. GDP, Jobs, and Fossil Largesse. Resilience, 30 November 2017. Available online: https:/ /www.resilience. org/stories/2017-11-30/gdp-jobs-and-fossil-largesse/ (accessed on 27 May 2021).

99. Friedemann, A. Energy Slaves: Every American Has Somewhere between 200 and 8000 Energy Slaves. Energy Skeptic, 5 April 2020. Available online: https:/ / energyskeptic.com/2020/energy-slaves/\#: \{\}:text=Energy $\% 20$ Slaves $\% 3 \mathrm{~A} \% 20$ every $\% 20$ American\%20has\%20somewhere\%20between\%20200\%20and\%208\%2C000\%20energy\%20slaves,-Posted\%20on\%20April (accessed on 27 May 2021).

100. Kilby, E.R. The Demographics of the U.S. Equine Population. In The State of the Animals; Salem, D.J., Rowan, A.N., Eds.; Humane Society Press: Washington, DC, USA, 2007; pp. 175-205, ISBN 9780974840093.

101. Daily, G.C.; Ehrlich, A.H.; Ehrlich, P.R. Optimum Human Population Size. Popul. Environ. 1994, 15, 469-475. [CrossRef]

102. Pimentel, D.; Harman, R.; Pacenza, M.; Pecarsky, J.; Pimentel, M. Natural Resources and an Optimum Human Population. Popul. Environ. 1994, 15, 347-369. [CrossRef]

103. Swan, S.H.; Colino, S. Count Down: How Our Modern World Is Threatening Sperm Counts, Altering Male and Female Reproductive Development, and Imperiling the Future of the Human Race; Scribner: New York, NY, USA, 2020; ISBN 9781982113667.

104. Rees, W.E. The fractal biology of plague and the future of civilization. J. Popul. Sustain. 2020, 5, 15-30.

105. Parsons, J. Population Control and Politics. Popul. Environ. 1991, 12, 355-377. [CrossRef]

106. Diamond, J.M. Collapse: How Societies Choose to Fail or Succeed; Penguin Books: New York, NY, USA, $2011 ;$ ISBN 9780143117001.

107. Hickey, C.; Rieder, T.N.; Earl, J. Population Engineering and the Fight against Climate Change. Soc. Theory Pract. 2016, 42, 845-870. [CrossRef]

108. Robinson, W.C.; Ross, J.A. The Global Family Planning Revolution: Three Decades of Population Policies and Programs; The World Bank: Washington, DC, USA, 2007; ISBN 9780821369517.

109. Wynes, S.; Nicholas, K.A. The Climate Mitigation Gap: Education and Government Recommendations Miss the Most Effective Individual Actions. Environ. Res. Lett. 2017, 12, 74024. [CrossRef]

110. Cave, D.; Bubola, E.; Sang-Hun, C. Long Slide Looms for World Population, with Sweeping Ramifications. New York Times, 22 May 2021. Available online: https:/ / www.nytimes.com/2021/05/22/world/global-population-shrinking.html (accessed on 27 May 2021).

111. Spratt, D.; Dunlop, I.; Taylor, L. Climate Reality Check 2020; Breakthrough National Center for Climate Restoration: Melbourne, Australia, 2020.

112. Polanyi, K. The Great Transformation: The Political and Economic Origins of Our Time, 2nd ed.; Beacon Press: Boston, MA, USA, 2001; ISBN 9780807056431. 